\title{
Temporal changes of deep-sea mesozooplankton abundance in the temperate NE Atlantic and estimates of the carbon budget
}

\author{
Rolf Koppelmann*, Horst Weikert \\ Institut für Hydrobiologie und Fischereiwissenschaft, Zeiseweg 9, D-22765 Hamburg, Germany
}

\begin{abstract}
Full-depth spring and summer vertical profiles of mesozooplankton numbers and biomass were obtained with a $1 \mathrm{~m}^{2}$ multiple opening/closing net and environmental sensing system (MOCNESS) from the BIOTRANS (biological vertical transport and energetics in the benthic boundary layer of the deep sea) study area $\left(47^{\circ} \mathrm{N}, 20^{\circ} \mathrm{W}\right)$ in the temperate NE Atlantic in 1992. Mesozooplankton abundance was high in spring and less in summer in the upper $750 \mathrm{~m}$. Between 750 and $1050 \mathrm{~m}$ differences between these seasons could not be detected. In the upper bathypelagic zone, between 1050 and $2250 \mathrm{~m}$, where abiotic fluctuations are minor, both mesozooplankton biomass and numbers were significantly higher in summer compared to spring. Samples from summer 1989 fitted this pattern. Calanoid copepods of the genus Metridia were the main contributors; most of the major zooplankton groups, though playing a subsidiary role, also showed a significant increase in summer in the upper bathypelagic zone. The increase probably was due to the large transient input of detrital material, which regularly occurred in the course of the phytoplankton spring bloom in the area investigated and may have stimulated the onset of reproduction in the bathypelagic zone. Temporal changes in mesozooplankton abundance could not be detected below $2250 \mathrm{~m}$ depth. Metabolic carbon requirements of mesozooplankton, calculated from ETS (electron transport system) data, increased in the bathypelagic zone (1000 to $4250 \mathrm{~m}$ ) from $1.61 \mathrm{mg} \mathrm{C} \mathrm{m} \mathrm{C} \mathrm{d}^{-1}$ in spring to $4.12 \mathrm{mg} \mathrm{C} \mathrm{m}^{-2} \mathrm{~d}^{-1}$ in summer The carbon respired by the bathypelagic micro- and mesozooplankton in summer, based on an assumed spring bloom area of $50000 \mathrm{~km}^{2}$, was $893 \mathrm{tC} \mathrm{d}^{-1}$ as a minimum estimate, which was higher than in spring by a factor of 2.6 .
\end{abstract}

KEY WORDS: NE Atlantic - Deep-sea zooplankton - Temporal changes - Carbon requirements

\section{INTRODUCTION}

Temporal changes in plankton abundance in the euphotic zone are primarily due to changing abiotic parameters (temperature, light, nutrients) and are well known for different areas of the ocean (e.g. Parsons \& Lalli 1988, Newton et al. 1994). The deep open ocean below $1000 \mathrm{~m}$ depth, however, is an environment where abiotic seasonal differences are of minor importance. Temperature is low $\left(<6\right.$ to $\left.7^{\circ} \mathrm{C}\right)$ and, like salinity ( $35 \mathrm{PSU}$ ) and oxygen concentrations, is stable over the year (Sverdrup et al. 1949, Menzies 1965, Mantyla \& Reid 1983, Tyler 1995). Annual cycles cannot be triggered by changes in light intensity or length of daytime since no surface light penetrates into these depths.

•E-mail: koppelmann@uni-hamburg.de
During the past 2 decades, the view that the deep sea is an environment of temporal stability has been basically modified due to observations of rapid deposition of detrital material from the euphotic zone to the abyssal deep-sea floor in the NE Atlantic (Billett et al. 1983, Lampitt 1985, Thiel et al. 1988/89, Riemann 1989, Rice et al. 1994), the NW Atlantic (Hecker 1990), the Pacific Ocean (Gardener et al. 1984, Smith et al. 1994), and possibly in other oceanic regions (see Gooday 1996). Such a nutritional input affects the community structure and taxonomic composition of deep-sea benthos (Loubere 1998 and literature cited therein). It stimulates sediment community oxygen consumption (Smith \& Baldwin 1984, Pfannkuche 1992, 1993, Smith et al. 1994), especially the reaction of bacteria (Turley \& Lochte 1990, Lochte 1992) as well as the production/recruitment of a number of macrobenthic species 
and some fish species (see Bishop \& Shalla 1994 and literature quoted therein). In the temperate NE Atlantic, the phytoplankton bloom varies in timing by as much as 6 wk each year (Rice et al. 1986), but it usually begins in early May. Observations confirm the old idea that 'at some places' in the acean a periodical variation of supply of food from the surface layer 'may give rise to a little annual excitement' at bathyal depths (Miosely 1880)

Temporal changes in abundance of holoplanktonic zooplankton in the deep sea below $1000 \mathrm{~m}$ have so far not been reported from temperate oceans. In this paper, we present zooplankton sampling series obtained by oblique hauls at consecutive discrete depth intervals from $4250 \mathrm{~m}$ to the surface during spring and summer surveys. We pose the hypothesis that the documented summer increase in zooplankton below $1000 \mathrm{~m}$ reflects a temporal signal as a response to flux events of spring bloom material from the surface layer. The influence of changing abundance of bathypelagic zooplankton on the carbon requirements will be discussed.
Table 1. Sampling and station data at the BIOTRANS site between the box comers $47^{\circ} 00^{\prime} \mathrm{N}, 19^{\circ} 28^{\prime} \mathrm{W}$ and $47^{\circ} 43^{\prime} \mathrm{N}, 20^{\circ} 02^{\prime} \mathrm{W}$. MOC- $1=1 \mathrm{~m}^{2} \mathrm{MOC}$ NESS, MOC-D $=1 \mathrm{~m}^{2}$ double MOCNESS. Local time = sampling time without lowering and raising the net. For more details see cruise reports (Zeitzschel et al. 1990, Pfannkuche et al. 1993)

\begin{tabular}{|lccr|}
\hline & Haul & Local time $(\mathrm{h})$ & Sampling depth $(\mathrm{m})$ \\
\hline 22 Aug 1989 & MOC-1-43 & $09: 35-10: 36$ & $1450-900$ \\
23 Aug 1989 & MOC-1-44 & $23: 25-00: 15$ & $1450-900$ \\
24 Aug 1989 & MOC-1-45 & $12: 19-13: 15$ & $1450-1050$ \\
25 Aug 1989 & MOC-1-46 & $00: 13-00: 49$ & $1450-900$ \\
25 Aug 1989 & MOC-1-47 & $10: 50-11: 44$ & $1450-900$ \\
25 Aug 1989 & MOC-1-48 & $21: 45-22: 36$ & $1450-900$ \\
21 Mar 1992 & MOC-1-70 & $22: 40-23: 18$ & $400-0$ \\
23 Mar 1992 & MOC-1-71 & $01: 29-03: 37$ & $4000-1650$ \\
25 Mar 1992 & MOC-1-72 & $00: 15-00: 45$ & $400-0$ \\
26 Mar 1992 & MOC-1-74 & $03: 55-05: 14$ & $1650-400$ \\
27 Mar 1992 & MOC-1-75 & $10: 50-12: 18$ & $1650-400$ \\
28 Mar 1992 & MOC-1-76 & $02: 50-05: 07$ & $4000-1650$ \\
31 Mar 1992 & MOC-1-77 & $13: 02-13: 36$ & $400-0$ \\
31 Mar 1992 & MOC-1-78 & $15: 51-17: 17$ & $1650-400$ \\
1 Apr 1992 & MOC-1-79 & $11: 07-12: 30$ & $1650-400$ \\
2 Apr 1992 & MOC-1-81 & $23: 07-00: 29$ & $1650-400$ \\
4 Apr 1992 & MOC-1-82 & $10: 04-10: 38$ & $400-0$ \\
5 Apr 1992 & MOC-1-83 & $02: 32-06: 17$ & $4250-3000$ \\
4 Aug 1992 & MOC-D-02 & $01: 20-03: 43$ & $400-0$ \\
5 Aug 1992 & MOC-D-03 & $04: 48-06: 43$ & $1450-0$ \\
11 Aug 1992 & MOC-D-05 & $09: 55-14: 17$ & $4250-2750$ \\
17 Aug 1992 & MOC-D-06 & $00: 14-03: 34$ & $4250-1050$ \\
20 Aug 1992 & MOC-D-07 & $17: 39-19: 54$ & $1450-0$ \\
23 Aug 1992 & MOC-D-08 & $07: 30-09: 52$ & $1450-0$ \\
24 Aug 1992 & MOC-D-09 & $05: 15-08: 50$ & $4250-1050$ \\
\hline
\end{tabular}

\section{MATERIAL AND METHODS}

We determined the abundance of mesozooplankton biomass and individual numbers (size class $<5 \mathrm{~mm}$, see Weikert \& Trinkaus 1990) at the mid-oceanic BlOTRANS (biological vertical transport and energetics in the benthic boundary layer of the deep sea) study area in the NE Atlantic $\left(47^{\circ} \mathrm{N}, 20^{\circ} \mathrm{W}\right.$, max. depth $\left.4550 \mathrm{~m}\right)$ during spring and summer in 1992 (Table 1). Samples from different depth intervals (Table 2) were taken by oblique hauls with a $1 \mathrm{~m}^{2}$ multiple closing net (MOCNESS; Wiebe et al. 1985) with a mesh aperture of $333 \mu \mathrm{m}$. The sampling speed was about 2 knots. The plankton samples were preserved in a $4 \%$ seawaterformaldehyde solution buffered with sodium tetraborate. Before sorting, the material was sieved through a $5 \mathrm{~mm}$ mesh and transferred to a fluid composed of $0.5 \%$ propylene-phenoxetol, $5.0 \%$ propylene glycol and $94.5 \%$ fresh water (Steedman 1976). The samples were wet weighed using the method of Tranter (1962). This method allowed further taxonomical analyses of the bathypelagic samples, which were too small to make aliquots for a more precise dry weight or carbon determination. Above $1050 \mathrm{~m}$, we mainly reported on the day samples of the investigated profiles (Koppel- mann 1995). Below this depth, all samples were combined since diel differences can be disregarded (Angel et al. 1982). Data from August 1989 (900 to $1450 \mathrm{~m}$ range only) which were obtained by the same method from the same area are shown as well (Table 1).

Zooplankton biomass (wet weight) and individual numbers were standardised to a per $1000 \mathrm{~m}^{3}$ basis; the mean values and the single data points were plotted on a logarithmic scale with depth at the midpoints of the intervals. The spring and summer vertical distributions of zooplankton below $1000 \mathrm{~m}$ were compared by means of a covariance analysis (Sokal \& Rohlf 1969) based on a power regression (Koppelmann \& Weikert 1992).

\section{RESULTS}

\section{Environmental setting}

Single temperature and salinity profiles (Fig. 1), monitored by the MOCNESS sensors on 1 April and 8 August 1992, showed clear temporal differences for the epipelagic zone. In summer, the upper $100 \mathrm{~m}$ was stratified, and temperature decreased with depth from 16 to $13^{\circ} \mathrm{C}$. Salinity showed a subsurface maximum of 
Table 2. Numbers of samples for each depth layer. $d=$ day, $N$ $=$ night, $\mathrm{R}=$ sunrise, $\mathrm{s}=$ sunset. $\mathrm{X}=$ no differentiation in time of day

\begin{tabular}{|c|c|c|c|c|c|c|c|c|}
\hline \multirow[t]{2}{*}{$\begin{array}{l}\text { Depth } \\
\text { interval } \\
\text { (m) }\end{array}$} & \multirow{2}{*}{$\begin{array}{c}\text { Meteor } 10 / 4 \\
22 \text { Aug } 89- \\
25 \text { Aug } 89 \\
X\end{array}$} & \multicolumn{3}{|c|}{$\begin{array}{c}\text { Meteor } 21 / 1 \\
21 \text { Mar } 92- \\
5 \text { Apr } 92\end{array}$} & \multicolumn{4}{|c|}{$\begin{array}{l}\text { Meteor } 21 / 6 \\
4 \text { Aug } 92- \\
25 \text { Aug } 92\end{array}$} \\
\hline & & $\mathrm{D}$ & $N$ & $\mathrm{X}$ & $\mathrm{R}$ & $\mathrm{D}$ & $S$ & $x$ \\
\hline $0-50$ & & 2 & 2 & & 1 & 1 & 1 & \\
\hline $50-100$ & & 2 & 2 & & 1 & 1 & 1 & \\
\hline $100-150$ & & 2 & 2 & & 1 & 1 & 1 & \\
\hline $150-200$ & & 2 & 2 & & 1 & 1 & 1 & \\
\hline $200-250$ & & 2 & 2 & & 1 & 1 & 1 & \\
\hline $250-300$ & & 2 & 2 & & 1 & 1 & 1 & \\
\hline $300-350$ & & 2 & 2 & & 1 & 1 & 1 & \\
\hline $350-400$ & & 2 & 2 & & 1 & 1 & 1 & \\
\hline $400-450$ & & 3 & 2 & & 1 & 1 & 1 & \\
\hline $450-600$ & & 3 & 2 & & 1 & 1 & 1 & \\
\hline $600-750$ & & 3 & 2 & & 1 & 1 & 1 & \\
\hline $750-900$ & & 3 & 2 & & 1 & 1 & 1 & \\
\hline $900-1050$ & 5 & 3 & 2 & & 1 & 1 & 1 & \\
\hline $1050-1250$ & 6 & & & 5 & & & & 5 \\
\hline $1250-1450$ & 6 & & & 5 & & & & 5 \\
\hline $1450-1650$ & & & & 5 & & & & 2 \\
\hline $1650-1850$ & & & & 2 & & & & 2 \\
\hline $1850-2050$ & & & & 2 & & & & 2 \\
\hline $2050-2250$ & & & & 2 & & & & 2 \\
\hline $2250-2500$ & & & & 2 & & & & 2 \\
\hline $2500-2750$ & & & & 2 & & & & 2 \\
\hline $2750-3000$ & & & & 2 & & & & 3 \\
\hline $3000-3500$ & & & & 3 & & & & \\
\hline $3000-3250$ & & & & & & & & 3 \\
\hline $3250-3500$ & & & & & & & & 3 \\
\hline $3500-3750$ & & & & & & & & 3 \\
\hline $3750-4000$ & & & & & & & & 3 \\
\hline $3500-4000$ & & & & 3 & & & & \\
\hline $4000-4250$ & & & & 1 & & & & 3 \\
\hline
\end{tabular}

35.7 PSU at $50 \mathrm{~m}$ depth and then decreased to 35.5 PSU at $200 \mathrm{~m}$. In spring the upper $200 \mathrm{~m}$ was mixed, exhibiting a temperature of $12^{\circ} \mathrm{C}$ and a salinity of 35.3 PSU. Investigations of Koeve et al. (1993) showed that the phytoplankton development had already started in March and depleted the available nutrients. Several storm events in spring 1992 prevented a permanent stratification and mixed the phytoplankton down into the deep water column. The sedimentation pattern resulted in a series of small pulses with the highest peaks in particle and chlorophyll flux occurring in March-April 1992 followed by further short flux events of smaller magnitude (Pfannkuche et al. 1999).

Below $100 \mathrm{~m}$ in summer, and $200 \mathrm{~m}$ in spring, temperature and salinity decreased to $7^{\circ} \mathrm{C}$ and $35.1 \mathrm{PSU}$, respectively, at $1000 \mathrm{~m}$ depth. However, the vertical variability of the data was higher in spring (Fig. 1). Between 1000 and $1500 \mathrm{~m}$ temperature and salinity decreased to $4^{\circ} \mathrm{C}$ and $34.8 \mathrm{PSU}$. Below this depth, salinity remained stable and temperature decreased slowly from 4 to $2.5^{\circ} \mathrm{C}$ at $4500 \mathrm{~m}$. Temporal differences were negligible below $1000 \mathrm{~m}$. The overall pattern in the deep water corresponds with the findings of the hydrographical investigations of Mittelstaedt et al. (1986) during the NOAMP (North Atlantic Monitoring Program) study at the same site.

\section{Zooplankton data}

Fig. 2 describes the bathymetric distributions of mesozooplankton in terms of total biomass and individual numbers with respect to spring and summer and in different years. In 1992, the abundance in the upper $750 \mathrm{~m}$ was high in spring and low in summer. The integral of total zooplankton numbers over this layer as indicated by the day data was higher by a factor of 4.2 in spring (27610 ind. $\mathrm{m}^{-2}$ ) than in summer (6570 ind. $\mathrm{m}^{-2}$ ). The respective daytime biomass values were $19480 \mathrm{mg} \mathrm{m}^{-2}$ in spring and $9690 \mathrm{mg} \mathrm{m}^{-2}$ in summer (Table 3), i.e. spring was higher by a factor of 2.0 . The summer/spring ratios (Table 4) of zooplankton and its major taxa derived from the integrals over this layer varied by at least a factor of 2 except for the malacostraca, which, in contrast, were more numerous in summer by a factor of 1.1 .

Temporal differences were less obvious between 750 and $1050 \mathrm{~m}$ depth (Fig. 2). The daytime standing crop was 2020 ind $\mathrm{m}^{-2}$ and $2200 \mathrm{mg} \mathrm{m}^{-2}$ in spring and 2030 ind. $\mathrm{m}^{-2}$ and $2280 \mathrm{mg} \mathrm{m}^{-2}$ in summer (Table 3 ). The similarity among seasons also holds true for most of the standing crops of the major zooplankton groups (Tables $3 \& 4$ ).

Integrated over the upper $1050 \mathrm{~m}$, day and night differences in terms of biomass and numbers in spring were 29 and $14 \%$, respectively. In summer, the re-

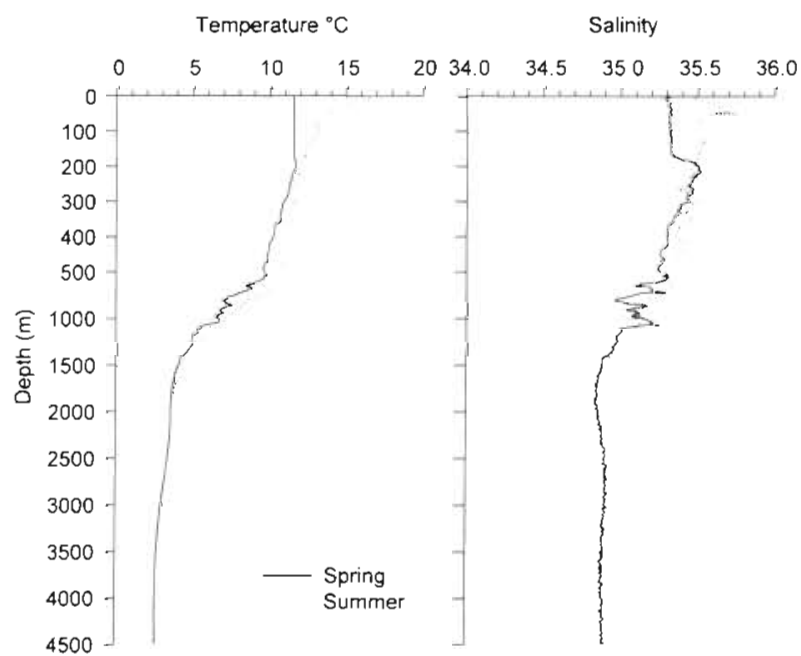

Fig. 1 Temperature and salinity distribution for a single cast in spring and summer 1992 

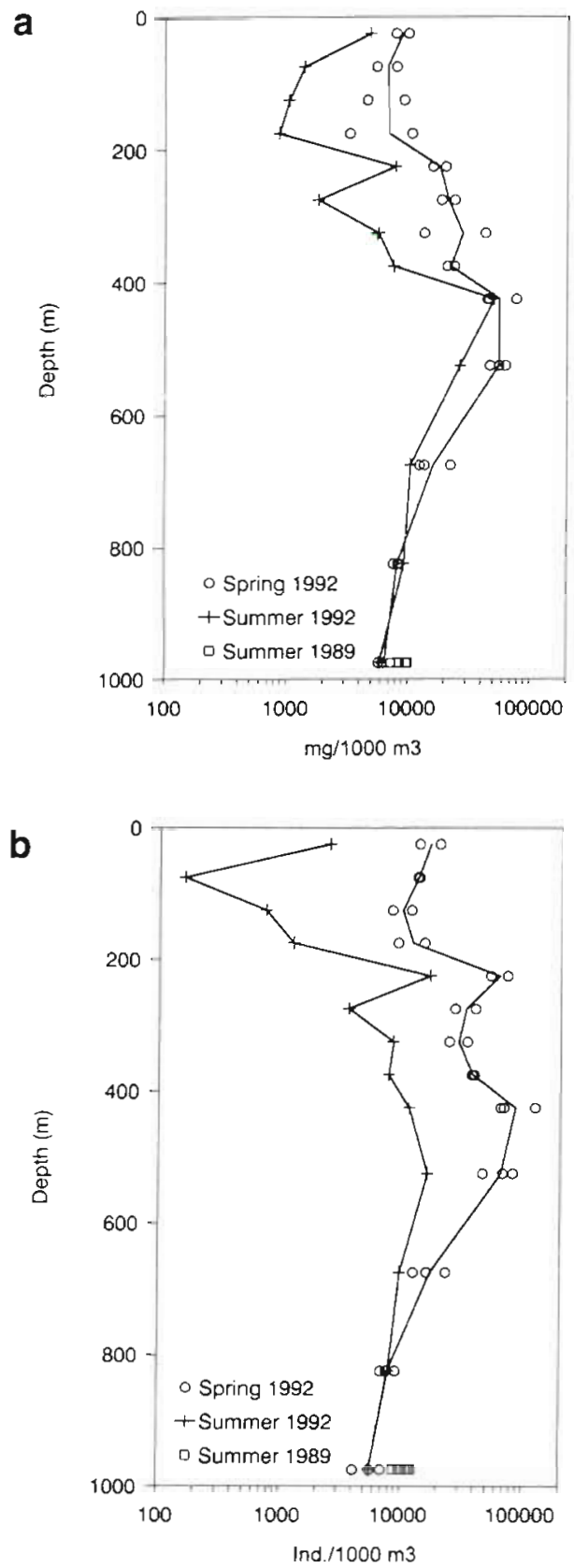

Fig. 2. Vertical distribution of zooplankton $\{a\}$ biomass and (b) abundance in spring and summer in the upper $1050 \mathrm{~m}$. Only day profiles are presented

spective integrals of biomass and individuals showed differences of less than 4 and $19 \%$ between daytime and sunset, and 44 and $21 \%$ between daytime and sunrise (Table 5). Maximum standing crops are not related to a particular time of the day.

In the upper bathypelagic zone, between 1050 and $2250 \mathrm{~m}$, the 1992 summer concentrations of total zooplankton and biomass exceeded the spring values of the same year; the extreme values of both seasons
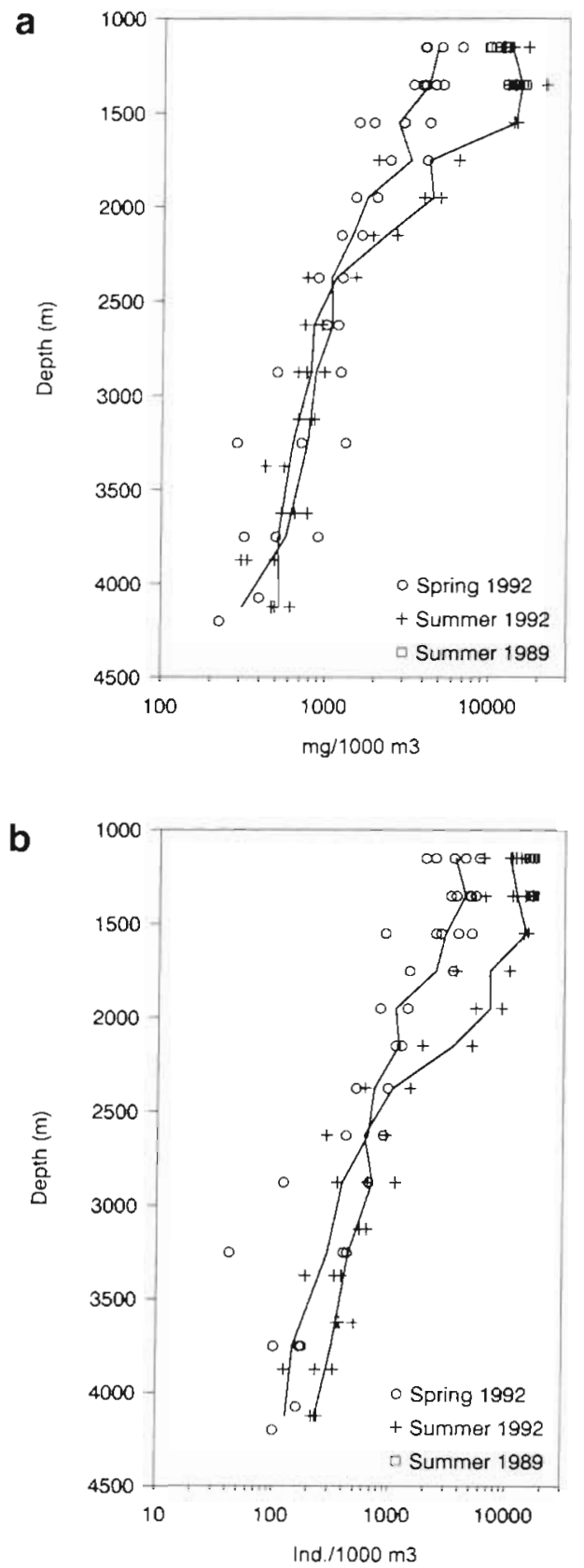

Fig. 3. Vertical distribution of zooplankton (a) biomass and (b) abundance in spring and summer below $1050 \mathrm{~m}$ regardless of time of the day

showed no overlap with one exception at 1650 to $1850 \mathrm{~m}$ depth (Fig. 3a). In spring, the standing crops in terms of numbers and biomass in the upper bathypelagic zone were 3090 ind $\mathrm{m}^{-2}$ and $3520 \mathrm{mg} \mathrm{m}^{-2}$ (Table 3). The respective values in summer were 10780 ind. $\mathrm{m}^{-2}$ and $10470 \mathrm{mg} \mathrm{m}^{-2}$. This gives a summer/spring ratio of 3.49 for the counts and 2.97 for the biomass, respectively (Table 4). In detail, siphonophore fragments were 7.06 times more abundant in 
Table 3. Standing crops of daytime mesozooplankton biomass and individual numbers (ind $\mathrm{m}^{-2}$ ) in spring and summer 1992 . The discrepancy between the total individual counts and the sum of the groups is due to smaller groups, which have been ornitted from the table. Ostracoda (Ostr), Copepoda (Cop) (= Calanoida [Cal] + Cyclopoida [Cycl] s.l. + Harpacticoida), Malacostraca (Mal), Chaetognatha (Chae), Polychaeta (Pol), Siphonophora fragments (Siph). NA: no data available

\begin{tabular}{|c|c|c|c|c|c|c|c|c|c|c|}
\hline $\begin{array}{l}\text { Depth } \\
\text { interval } \\
\text { (m) }\end{array}$ & $\begin{array}{c}\text { Total } \\
\text { biomass } \\
\left(\mathrm{mg} \mathrm{m}^{-2}\right)\end{array}$ & $\begin{array}{c}\text { Total } \\
\text { abundance } \\
\text { (ind. } \mathrm{m}^{-2} \text { ) }\end{array}$ & $\begin{array}{c}\text { Ostr } \\
\text { (ind } \mathrm{m}^{-2} \text { ) }\end{array}$ & $\begin{array}{c}\text { Cop } \\
\text { (ind } \mathrm{m}^{-2} \text { ) }\end{array}$ & $\begin{array}{c}\text { Cal } \\
\text { (ind. } \mathrm{m}^{-2} \text { ) }\end{array}$ & $\begin{array}{c}\text { Cycl } \\
\text { (ind } \mathrm{m}^{-2} \text { ) }\end{array}$ & $\begin{array}{c}\text { Mal } \\
\text { (ind. } \mathrm{m}^{-2} \text { ) }\end{array}$ & $\begin{array}{l}\text { Chae } \\
\text { (ind. } \mathrm{m}^{-2} \text { ) }\end{array}$ & $\begin{array}{c}\text { Pol } \\
\text { (ind. } \mathrm{m}^{-2} \text { ) }\end{array}$ & $\begin{array}{c}\text { Siph } \\
\text { (ind. } \mathrm{m}^{-2} \text { ) }\end{array}$ \\
\hline \multicolumn{11}{|l|}{ Spring 1992} \\
\hline $0-50$ & 441.0 & 835.9 & 10.2 & 629.9 & 503.4 & 126.5 & 99.3 & 44.7 & NA & 14.7 \\
\hline $50-100$ & 332.0 & 668.7 & 6.3 & 441.9 & 291.8 & 150.1 & 39.1 & 39.0 & NA & 12.5 \\
\hline $100-150$ & 340.8 & 495.3 & 3.0 & 293.2 & 169.9 & 123.4 & 42.9 & 34.7 & NA & 28.2 \\
\hline $150-200$ & 345.7 & 604.8 & 4.3 & 364.3 & 203.9 & 160.4 & 67.4 & 75.0 & NA & 34.1 \\
\hline $200-250$ & 897.9 & 3153.7 & 5.7 & 2832.3 & 2676.7 & 155.6 & 51.3 & 245.3 & NA & 116.8 \\
\hline $250-300$ & 1065.2 & 1675.0 & 99.0 & 1463.0 & 1363.8 & 99.2 & 128 & 72.4 & $\mathrm{NA}$ & 39.0 \\
\hline $300-350$ & 1401.6 & 1464.8 & 177.7 & 1228.1 & 1175.2 & 52.9 & 1.4 & 40.9 & $\mathrm{NA}$ & 27.3 \\
\hline $350-400$ & 1114.6 & 1917.3 & 145.0 & 1651.4 & 1606.1 & 45.2 & 4.7 & 84.1 & NA & 31.7 \\
\hline $400-450$ & 2795.1 & 4324.1 & 450.3 & 3652.6 & 2458.9 & 247.5 & 36.1 & 162.1 & NA & 14.6 \\
\hline $450-600$ & 8311.9 & 9865.6 & 969.0 & 8690.0 & 6372.5 & 1267.9 & 44.3 & 136.8 & NA & 72.2 \\
\hline $600-750$ & 2429.6 & 2609.4 & 111.5 & 2404.0 & 2407.5 & 69.4 & 6.9 & 69.5 & NA. & 13.7 \\
\hline $0-750$ & 19475.4 & 27614.6 & 1976.4 & 23650.7 & 19229.7 & 2498.1 & 406.1 & 1004.7 & - & 404.8 \\
\hline $\begin{array}{l}750-900 \\
900-1050\end{array}$ & $\begin{array}{r}1225.8 \\
969.7\end{array}$ & $\begin{array}{r}1181.1 \\
837.3\end{array}$ & $\begin{array}{l}64.7 \\
46.6\end{array}$ & $\begin{array}{r}1043.0 \\
713.4\end{array}$ & $\begin{array}{r}1060.8 \\
570.8\end{array}$ & $\begin{array}{l}21.6 \\
45.6\end{array}$ & $\begin{array}{l}13.8 \\
27.5\end{array}$ & $\begin{array}{l}44.3 \\
42.6\end{array}$ & $\begin{array}{l}\text { NA } \\
\text { NA }\end{array}$ & $\begin{array}{l}18.4 \\
12.7\end{array}$ \\
\hline $750-1050$ & 2195.5 & 2018.4 & 111.4 & 1756.4 & 1631.6 & 67.2 & 41.3 & 86.9 & - & 31.1 \\
\hline $1050-1250$ & 795.8 & 692.7 & 31.9 & 585.3 & 544.1 & 41.2 & 23.4 & 38.1 & 4.9 & 11.5 \\
\hline $1250-1450$ & 828.7 & 843.7 & 35.8 & 756.7 & 706.2 & 50.5 & 10.8 & 33.2 & 3.6 & 7.8 \\
\hline $1450-1650$ & 541.1 & 573.3 & 20.8 & 521.2 & 471.7 & 49.5 & 8.0 & 19.5 & 1.3 & 5.1 \\
\hline $1650-1850$ & 649.2 & 474.1 & 27.9 & 423.3 & 374.9 & 48.4 & 5.8 & 16.0 & 1.3 & 5.2 \\
\hline $1850-2050$ & 350.5 & 216.9 & 14.3 & 194.4 & 172.9 & 20.7 & 2.0 & 3.7 & 0.7 & 0.7 \\
\hline $2050-2250$ & 355.6 & 289.5 & 12.4 & 267.3 & 232.0 & 34.8 & 1.9 & 5.4 & 0.3 & 0.8 \\
\hline $1050-2250$ & 3520.9 & 3090.2 & 143.1 & 2748.2 & 2501.8 & 245.1 & 51.9 & 115.9 & 12.1 & 31.1 \\
\hline $2250-2500$ & 266.0 & 180.0 & 14.0 & 161.2 & 153.6 & 7.6 & 1.6 & 2.1 & 0.1 & 0.6 \\
\hline $2500-2750$ & 271.2 & 159.3 & 12.5 & 137.5 & 127.7 & 8.1 & 1.9 & 4.7 & 1.3 & 0.0 \\
\hline $2750-3000$ & 215.6 & 96.2 & 10.5 & 80.9 & 68.9 & 11.9 & 1.3 & 2.6 & 0.2 & 1.1 \\
\hline $3000-3500$ & 385.7 & 143.9 & 18.4 & 107.1 & 97.8 & 8.7 & 6.3 & 11.0 & 0.7 & 2.0 \\
\hline $3500-4000$ & 287.1 & 74.2 & 6.8 & 60.1 & 54.7 & 4.9 & 2.3 & 4.0 & 0.7 & 1.0 \\
\hline $4000-4250$ & 81.9 & 34.0 & 3.7 & 27.8 & 23.4 & 3.9 & 0.7 & 0.6 & 0.2 & 0.7 \\
\hline $2250-4250$ & 1507.5 & 687.6 & 65.9 & 574.6 & 526.1 & 45.1 & 14.1 & 25.0 & 3.2 & 5.4 \\
\hline \multicolumn{11}{|c|}{ Summer 1992} \\
\hline $0-50$ & 241.1 & 124.0 & 10.4 & 93.7 & 92.3 & 1.4 & 13.4 & 5.1 & NA & 1.6 \\
\hline $50-100$ & 69.2 & 8.0 & 0.3 & 5.4 & 3.3 & 2.0 & 2.0 & 0.0 & NA & 0.3 \\
\hline $100-150$ & 51.9 & 37.5 & 0.8 & 35.6 & 24.8 & 10.8 & 0.5 & 0.3 & NA & 0.0 \\
\hline $150-200$ & 42.9 & 63.1 & 1.6 & 59.7 & 57.7 & 2.0 & 1.0 & 0.8 & NA & 0.0 \\
\hline $200-250$ & 389.8 & 845.4 & 271.3 & 527.1 & 487.1 & 40.0 & 7.9 & 35.4 & NA & 17.1 \\
\hline $250-300$ & 90.6 & 180.9 & 8.9 & 157.8 & 154.3 & 3.5 & 3.0 & 10.2 & NA & 1.3 \\
\hline $300-350$ & 283.3 & 422.5 & 31.7 & 359.7 & 353.9 & 5.8 & 3.5 & 18.4 & NA & 8.1 \\
\hline $350-400$ & 378.2 & 388.4 & 6.9 & 364.0 & 360.6 & 3.5 & 6.4 & 8.3 & NA & 7.6 \\
\hline $400-450$ & 2542.0 & 575.0 & 18.2 & 367.0 & 358.3 & 8.7 & 173.8 & 16.0 & NA & 16.7 \\
\hline $450-600$ & 4021.2 & 2457.5 & 192.4 & 1922.2 & 1845.6 & 65.4 & 227.1 & 102.7 & $\mathrm{NA}$ & 63.5 \\
\hline $600-750$ & 1577.0 & 1463.3 & 120.1 & 1196.6 & 1081.1 & 115.5 & 16.3 & 86.2 & NA & 49.3 \\
\hline $0-750$ & 9687.2 & 6565.7 & 391.4 & 5088.7 & 4818.9 & 258.6 & 455.0 & 283.6 & - & 165.6 \\
\hline $\begin{array}{l}750-900 \\
900-1050\end{array}$ & $\begin{array}{r}1398.5 \\
883.4\end{array}$ & $\begin{array}{r}1189.7 \\
842.7\end{array}$ & $\begin{array}{r}147.8 \\
56.7\end{array}$ & $\begin{array}{l}937.0 \\
704.2\end{array}$ & $\begin{array}{l}881.7 \\
664.2\end{array}$ & $\begin{array}{l}55.3 \\
40.0\end{array}$ & $\begin{array}{l}16.2 \\
22.5\end{array}$ & $\begin{array}{l}70.7 \\
50.1\end{array}$ & $\begin{array}{l}\text { NA } \\
\text { NA. }\end{array}$ & $\begin{array}{l}55.3 \\
18.9\end{array}$ \\
\hline $750-1050$ & 2281.9 & 2032.4 & 204.5 & 1641.2 & 1546.7 & 95.2 & 38.7 & 120.8 & - & 74.2 \\
\hline $1050-1250$ & 2502.2 & 2030.5 & 84.8 & 1806.9 & 1687.3 & 119.6 & 58.0 & 54.5 & 10.3 & 48.2 \\
\hline $1250-1450$ & 2853.9 & 2321.6 & 84.7 & 2011.6 & 1850.5 & 160.8 & 96.0 & 68.6 & 32.3 & 55.1 \\
\hline $1450-1650$ & 2809.1 & 2797.8 & 50.9 & 2538.5 & 2088.8 & 449.8 & 98.0 & 54.7 & 25.3 & 85.5 \\
\hline $1650-1850$ & 842.0 & 3381.0 & 12.5 & 1339.0 & 1000.8 & 338.2 & 5.7 & 15.8 & 4.2 & 25.1 \\
\hline $1850-2050$ & 886.4 & 1402.8 & 11.8 & 1379.3 & 995.2 & 384.1 & 3.2 & 3.4 & 2.2 & 3.1 \\
\hline $2050-2250$ & 574.7 & 850.3 & 17.4 & 823.1 & 615.0 & 208.1 & 1.8 & 2.3 & 5.6 & 2.6 \\
\hline $1050-2250$ & 10468.3 & 10784.0 & 262.1 & 9898.4 & 8237.6 & 1660.6 & 262.7 & 199.3 & 79.9 & 219.6 \\
\hline $2250-2500$ & 283.0 & 259.2 & 12.3 & 238.0 & 213.4 & 24.6 & 2.0 & 3.2 & 2.4 & 0.7 \\
\hline $2500-2750$ & 208.7 & 149.4 & 12.3 & 132.1 & 129.2 & 3.0 & 2.7 & 2.1 & 0.2 & 1.1 \\
\hline $2750-3000$ & 200.5 & 174.4 & 15.9 & 151.1 & 143.0 & 8.1 & 2.6 & 3.3 & 0.8 & 0.6 \\
\hline $3000-3500$ & 312.2 & 219.1 & 20.4 & 169.7 & 165.5 & 3.6 & 4.9 & 13.8 & 1.3 & 1.6 \\
\hline $3500-4000$ & 257.8 & 159.1 & 14.7 & 124.1 & 117.5 & 4.4 & 3.4 & 13.5 & 0.9 & 0.9 \\
\hline $4000-4250$ & 131.5 & 58.0 & 10.7 & 41.1 & 37.5 & 3.3 & 1.2 & 4.6 & 0.4 & 1.3 \\
\hline $2250-4250$ & 1393.7 & 1019.2 & 86.3 & 856.1 & 806.1 & 47.0 & 16.8 & 40.5 & 6.0 & 6.2 \\
\hline
\end{tabular}


summer than in spring, followed by the cyclopoid copepods sensu lato (s.l.) (6.78) and the polychaetes (6.60). Malacostracans (5.06) and calanoid copepods (3.29) held an intermediate position. The summer/ spring ratios of the ostracods (1.83) and the chaetognaths (1.72) were the lowest. For the latter 2 groups and for the malacostracans, the summer increase was most pronounced in the 1050 to $1650 \mathrm{~m}$ layer.

The changes in total abundance of mesozooplankton (Fig. 3b) in the 1050 to $2250 \mathrm{~m}$ layer were primarily caused by the calanoid copepods, which comprised $81.0 \%$ of the total standing crop in spring and $76.4 \%$ in summer. Metridinidae were abundant in this zone, comprising $14.4 \%$ of the calanoid standing crop during spring, but $59.1 \%$ during summer. In absolute numbers, the standing crop of the Metridinidae, which was almost exclusively comprised of the genus Metridia. increased by a factor of 13.5 , i.e. from 360 ind. $\mathrm{m}^{-2}$ in spring to 4870 ind. $\mathrm{m}^{-2}$ in summer. The ontogenetical composition of the genus was examined by 1 profile each in spring and summer. In spring, adult females contributed $5.1 \%$ to the generic standing crop, adult males $7.5 \%, \mathrm{CV}$ copepodites $54.6 \%$ and younger stages $32.8 \%$. In summer, juveniles had become even more in comparison to the sexes in terms of both relative and absolute numbers: adult females $(0.03 \%)$ and males $(0.1 \%)$ were nearly absent, CV copepodites predominated with $97.7 \%$, while the presence of younger stages was minor $(2.2 \%)$.

Below $2250 \mathrm{~m}$, in the lower bathypelagic zone, the biomass standing crops were quite similar in spring and summer, amounting to 1510 and $1390 \mathrm{mg} \mathrm{m}^{-2}$, respectively, whereas the individual counts indicate higher numbers in summer which were higher by a factor of $1.48\left(1020\right.$ ind $\mathrm{m}^{-2}$ ) than those in spring (690 ind $\mathrm{m}^{-2}$; Tables $3 \& 4$ ). This feature is also reflected by the counts of the major zooplankton groups, except for the polychaetes and chaetognaths, which were higher in summer by a factor of 1.88 and 1.62 , respectively. Metridinidae comprised $25.0 \%$ of the calanoid standing crop in spring and $22.0 \%$ in summer, with absolute numbers of 130 and 180 ind. $\mathrm{m}^{-2}$, respectively.

Table 4. Summer/spring ratios of total biomass and individual counts in 1992, based on the abundances $\mathrm{m}^{-2}$ in Table 2 . Abbreviations as in Table 2 . Above $1050 \mathrm{~m}$, only day data are used. NA = no data available

\begin{tabular}{|c|c|c|c|c|c|c|c|c|c|c|}
\hline \multirow{2}{*}{$\begin{array}{l}\text { Depth } \\
\text { interval } \\
\text { (m) }\end{array}$} & \multicolumn{10}{|c|}{ Summer/spring ratios } \\
\hline & $\begin{array}{c}\text { Total } \\
\text { biomass }\end{array}$ & $\begin{array}{c}\text { Total } \\
\text { abundance }\end{array}$ & Ostr & Cop & Cal & Cycl & Mal & Chae & Pol & Siph \\
\hline $0-50$ & 0.55 & 0.15 & 1.01 & 0.15 & 0.18 & 0.01 & 0.14 & 0.11 & NA & 0.11 \\
\hline $50-100$ & 0.21 & 0.01 & 0.05 & 0.01 & 0.01 & 0.01 & 0.05 & 0.00 & $\mathrm{NA}$ & 0.03 \\
\hline $100-150$ & 0.15 & 0.08 & 0.28 & 0.12 & 0.15 & 0.09 & 0.01 & 0.01 & NA & 0.00 \\
\hline $150-200$ & 0.12 & 0.10 & 0.38 & 0.16 & 0.28 & 0.01 & 0.01 & 0.01 & NA & 0.00 \\
\hline $200-250$ & 0.43 & 0.27 & $47.17^{a}$ & 0.19 & 0.18 & 0.26 & 0.15 & 0.14 & NA & 0.15 \\
\hline $250-300$ & 0.09 & 0.11 & 0.09 & 0.11 & 0.11 & 0.04 & 0.23 & 0.14 & NA & 0.03 \\
\hline $300-350$ & 0.20 & 0.29 & 0.18 & 0.29 & 0.30 & 0.11 & 2.50 & 0.45 & NA & 0.30 \\
\hline $350-400$ & 0.34 & 0.20 & 0.05 & 0.22 & 0.22 & 0.08 & 1.38 & 0.10 & NA & 0.24 \\
\hline $400-450$ & 0.91 & 0.13 & 0.04 & 0.10 & 0.15 & 0.04 & 4.82 & 0.10 & NA & 1.15 \\
\hline $450-600$ & 0.48 & 0.25 & 0.20 & 0.22 & 0.29 & 0.05 & 5.13 & 0.75 & NA & 0.88 \\
\hline $600-750$ & 0.65 & 0.56 & 1.08 & 0.50 & 0.45 & 1.66 & 2.36 & 1.24 & NA & 3.59 \\
\hline $0-750$ & 0.50 & 0.24 & 0.20 & 0.22 & 0.25 & 0.10 & 1.12 & 0.28 & - & 0.41 \\
\hline $750-900$ & 1.14 & 1.01 & 2.28 & 0.90 & 0.83 & 2.56 & 1.17 & 1.59 & NA & 3.01 \\
\hline $900-1050$ & 0.91 & 1.01 & 1.22 & 0.99 & 1.16 & 0.88 & 0.82 & 1.18 & $\mathrm{NA}$ & 1.49 \\
\hline $750-1050$ & 1.04 & 1.01 & 1.84 & 0.93 & 0.95 & 1.42 & 0.94 & 1.39 & - & 2.38 \\
\hline $1050-1250$ & 3.14 & 2.93 & 2.66 & 3.09 & 3.10 & 2.90 & 2.48 & 1.43 & 2.10 & 4.19 \\
\hline $1250-1450$ & 3.44 & 2.75 & 2.37 & 2.66 & 2.62 & 3.18 & 8.89 & 2.07 & 8.97 & 7.06 \\
\hline $1450-1650$ & 5.19 & 4.88 & 2.45 & 4.87 & 4.43 & 9.09 & 12.25 & 2.81 & 19.46 & 16.76 \\
\hline $1650-1850$ & 1.30 & 2.91 & 0.45 & 3.16 & 2.67 & 6.99 & 0.98 & 0.99 & 3.23 & 4.83 \\
\hline $1850-2050$ & 2.53 & 6.47 & 0.83 & 7.10 & 5.76 & 18.56 & 1.60 & 0.92 & 3.14 & 4.43 \\
\hline $2050-2250$ & 1.62 & 2.94 & 1.40 & 3.08 & 2.65 & 5.98 & 0.95 & 0.43 & 18.67 & 3.25 \\
\hline $1050-2250$ & 2.97 & 3.49 & 1.83 & 3.60 & 3.29 & 6.78 & 5.06 & 1.72 & 6.60 & 7.06 \\
\hline $2250-2500$ & 1.06 & 1.44 & 0.88 & 1.48 & 1.39 & 3.24 & 1.25 & 1.52 & 24.00 & 1.17 \\
\hline $2500-2750$ & 0.77 & 0.94 & 0.98 & 0.96 & 1.01 & 0.37 & 1.42 & 0.45 & 0.15 & - \\
\hline $2750-3000$ & 0.93 & 1.81 & 1.51 & 1.87 & 2.08 & 0.68 & 2.00 & 1.27 & 4.00 & 0.55 \\
\hline $3000-3500$ & 0.81 & 1.52 & 1.11 & 1.58 & 1.69 & 0.41 & 0.78 & 1.25 & 1.86 & 0.80 \\
\hline $3500-4000$ & 0.90 & 2.14 & 2.16 & 2.06 & 2.15 & 0.90 & 1.48 & 3.38 & 1.29 & 0.90 \\
\hline $4000-4250$ & 1.61 & 1.71 & 2.89 & 1.48 & 1.60 & 0.85 & 1.71 & 7.67 & 2.00 & 1.86 \\
\hline $2250-4250$ & 0.92 & 1.48 & 1.31 & 1.49 & 1.53 & 1.04 & 1.19 & 1.62 & 1.88 & 1.18 \\
\hline
\end{tabular}


Table 5. Standing crops of biomass $\left(\mathrm{mg} \mathrm{m}^{-2}\right.$ ) and individuais (ind. $\mathrm{m}^{-2}$ ) in the upper $1050 \mathrm{~m}$ of the water column

\begin{tabular}{|c|c|c|c|c|c|c|c|c|}
\hline & \multicolumn{2}{|c|}{ Day } & \multicolumn{2}{|c|}{ Sunset } & \multicolumn{2}{|c|}{ Sunrise } & \multicolumn{2}{|c|}{ Night } \\
\hline & $\left(\mathrm{mg} \mathrm{m}^{-2}\right)$ & (ind. $\mathrm{m}^{-2}$ ) & $\left(\mathrm{mg} \mathrm{m}^{-2}\right)$ & (ind. $\mathrm{m}^{-2}$ ) & $\left(\mathrm{mg} \mathrm{m}^{-2}\right)$ & (ind. $\mathrm{m}^{-2}$ ) & $\left(\mathrm{mg} \mathrm{m}^{-2}\right)$ & (ind $\mathrm{m}^{-2}$ ) \\
\hline Spring & 21670 & 29630 & - & - & & - & 16780 & 33770 \\
\hline Summer & 11970 & 8600 & 12470 & 10280 & 8640 & 7810 & - & - \\
\hline
\end{tabular}

Table 6. p-values for summer/spring differences below $1050 \mathrm{~m}$ obtained by a power regression and an analysis of covariance. p-values of $y$-intercepts present only if no significant differences occur between the slopes $(p>0.050)$

\begin{tabular}{|lrc|}
\hline Group & Slope & $y$-intercept \\
\hline Total biomass & $<0.001$ & \\
Total individuals & 0.060 & $<0.001$ \\
Ostracoda & 0.898 & $<0.001$ \\
Copepoda & 0.034 & \\
Calanoida & 0.065 & $<0.001$ \\
Cyclopoida 5.1. & 0.001 & \\
Malacostraca & 0.143 & 0.011 \\
Chaetognatha & 0.085 & \\
Polychaeta & 0.027 & \\
Siphonophora fragments & 0.019 & \\
\hline
\end{tabular}

Overall, the vertical distribution in spring and summer 1992 in the bathypelagic zone (>1000 m), compared using an analysis of covariance, revealed significant differences, in either the slopes or in the $y$-intercepts of the vertical profiles (Table 6). As for the total biomass, the decrease in numbers of cyclopoids s.l., polychaetes and siphonophore fragments with depth was significantly greater in summer than in spring, obviously due to the greater elevated individual numbers of these taxa in the 1050 to $2250 \mathrm{~m}$ layer. The numbers of total mesozooplankton, ostracods, calanoids, malacostracans and chaetognaths were also significantly higher in summer, but there were no significant differences in the shape of the vertical distribution.

The limited summer 1989 data available from the depth layers at 900 to 1050,1050 to 1250 and 1250 to $1450 \mathrm{~m}$ were in accord with concentrations obtained from the same layers in summer 1992 (Fig. 3)

\section{DISCUSSION}

\section{Temporal changes in biomass and abundance of mesozooplankton}

Our study in the temperate NE Atlantic revealed for the first time a significant temporal change in bathypelagic zooplankton at a midlatitude site as indicated by an increase in terms of numbers and biomass from spring to summer in the upper bathypelagic realm $(1050$ to $2250 \mathrm{~m})$. Detrital material is assumed to be the major food source for zooplankton in the deep sea (Alldredge \& Silver 1988, Lampitt 1992, Steinberg et al. 1998 and literature cited in these studies). Although direct information from our study is lacking, loss of sinking surface-born material in the bathypelagic zone due to feeding of zooplankton is evidenced by algal cells found in some deep-sea phaeodarians and particle-feeding copepods (Gowing \& Wishner 1992). There are 3 arguments why the quantitative differences between the sampling periods can reasonably be seen in context with the transient mass injection of phytoplankton spring bloom material which was subsequently found at the sea floor in the area during the summer survey (Pfannkuche et al. 1999).

(1) Increased zooplankton abundances at depths greater than $1000 \mathrm{~m}$ are known for boreal regions of the ocean during autumn and winter, and they are coupled, in general, with a faunistic change (e.g. Vinogradov 1968). In most cases this phenomenon is due to diapausing stages of some prominent epipelagic, herbivorous calanoid copepod species (e.g. Vinogradov 1968, Hirche 1983, Kaartvedt 1996) which submerge at the end of the vegetation period. In contrast, the summer increase in the bathypelagic community in the BIOTRANS area was accompanied by an increase in virtually all major zooplankton groups, although calanoid copepods (Table 3), predominantly Metridia species, were the main contributors. A species-specific analysis of this omnivorous genus (Timonin 1971, Gapishko 1980) has not yet been made for our material, but the overwhelming majority of the Metridia specimens in the bathypelagic zone differed in their habitus from those living in shallower layers, irrespective of the time of day or season. Hence, a seasonal and/or diel feeding migration of the component copepod fauna, which would result in a vertical shift of a substantial amount of zooplankton from the upper layers into the bathypelagic zone and vice versa, is unlikely. The diel differences in the total zooplankton abundance in the upper $1050 \mathrm{~m}$ are not conclusive in this respect (Table 5) and do not contradict the acknowledged view that diel migration below $1000 \mathrm{~m}$ can be disregarded (Angel et al. 1982). 
(2) Unlike the situation at high latitudes, the increment in the standing crop of mesozooplankton in the bathypelagic zone of the BIOTRANS area in summer 1992 was not due to a shortage of food. As exemplified for the principal zooplankton taxon, the calanoid Metridinidae, the enrichment in zooplankton abundance in the upper bathypelagic zone was probably due to reproduction, which implies good food conditions in a preceding period. It is noteworthy that the slight prevalence of males during both seasonal surveys contrasts to the high proportion of females among sexes, which is typical of deep-sea zooplankton (Wishner 1980 and literature cited therein). In the course of reproduction, males are generally assumed to appear prior to females in calanoid copepods, indicating the close onset of mating, in addition to low adult numbers (Kouwenberg 1993). This finding and the absolute and relative increase of $\mathrm{CV}$ copepodites in summer would point towards a reproduction cycle of the deep-living Metridia population not exceeding $140 \mathrm{~d}$. The time span agrees with calculations on the generation times of subarctic North Atlantic zooplankton, which is subjected to similar low temperatures (see Diel 1988 and literature cited therein). The data on the Metridia population are a strong argument for the presence of a temporal shift in the abundance of total zooplankton and argue against the existence of a substantial effect of mesoscale spatial heterogeneity.

(3) Assuming the summer increase in bathypelagic zooplankton was related to food-falls of phytodetritus or some other kind of detrital material, then, an increase in bathypelagic zooplankton abundance must be absent in regions which lack a spring bloom and subsequent sinking of agglomerates. Indeed, Roe's (1988) summer profiles from the oligotrophic Madeira Abyssal Plain area at $31^{\circ} 17^{\prime} \mathrm{N}, 25^{\circ} 24^{\prime} \mathrm{W}$, where phytodetritus events do not appear (Rice et al. 1994), showed the same slope as the BIOTRANS spring data from 1988 (Koppelmann \& Weikert 1992). Both sets of profiles are also not dissimilar from the 1992 spring profile from the BIOTRANS site $(\mathrm{p}=0.138$ and $\mathrm{p}=0.098$, respectively). Also, in accord with our hypothesis, the data from Angel \& Baker (1982), which were obtained during spring 1978 at $42^{\circ} \mathrm{N}, 17^{\circ} \mathrm{W}$, closer to the $\mathrm{BIO}$ TRANS area, showed a slope similar to that of our spring profiles (Koppelmann \& Weikert 1992).

Three aspects should be addressed by future studies in the field in order to improve the possible association between increasing zooplankton abundance and episodic events of phytodetritus falls.

(1) There was not a well-established single bloom event in the BIOTRANS area in 1992. Due to several storm events, the surface layer was mixed in intervals and a number of episodic and temporally variable phytoplankton blooms occurred during the study pe- riod (Koeve et al. 1993). This suggests a series of smaller flux events of phytodetritus or some other kind of phytoplankton-derived material into the deep sea over an extended period of time. At the deep sea bottom, the succession of small pulses of detrital material caused only short reactions in sediment community activity (Pfannkuche et al. 1999). Despite the high average settling rate of $\sim 100 \mathrm{~m} \mathrm{~d}^{-1}$ (Billett et al. 1983, Alldredge \& Silver 1988), the time available for bathypelagic organisms to access potential food particles and thus for reproduction to be initiated would have been greater, as compared to a major flux event of phytodetritus which was observed in 1986 (Thiel et al. 1988/1989). A different, major event caused by a salp bloom in 1988 prevented the build up of a typical phytoplankton spring bloom (Stienen et al. 1988) in the BIOTRANS area and induced a massive fall of fastsinking salp faeces (Pfannkuche \& Lochte 1993) and carcasses, which had heavily contaminated the zooplankton samples (Koppelmann 1994). No data on summer zooplankton from 1988, however, are available to enable us to study the possible biological effect of this fall, whilst the poor zooplankton data from August 1989 (Table 1) does not include information on the phytoplankton spring bloom and zooplankton abundance. We, therefore, cannot rule out the possibility that the observed increase in deep-living zooplankton is irregularly coupled with the settlement of spring bloom material, depending on the mode of detrital flux.

(2) The surface source area for a trap sample collected over 2 mo at $3200 \mathrm{~m}$ depth has been estimated at $\leq 200 \mathrm{~km}$ in diameter (Deuser et al. 1990, Newton et al. 1994). This compares to observed mesoscale eddy structures (Savidge et al. 1992, Robinson et al. 1993) and surface-water chlorophyll concentrations in the area (Watson et al. 1991, Hoge \& Swift 1993, Yoder et al. 1993) which form a bloom mosaic over a large ocean area of at least $50000 \mathrm{~km}^{2}$ in size (Newton et al. 1994). Significant differences in sedimentation patterns on a mesoscale may thus be generated as shown by the authors, who compared results from traps deployed $100 \mathrm{~km}$ away (Honjo \& Manganini 1993). We have no information on production and destruction processes at the location of our deep-sea profiles relative to the surface source area of the fluxes delivered to the bathypelagic zone or, hence, on the coupling of the development of the mesozooplankton in the bathypelagic zone to a particular mesoscale surface bloom pattern. Due to this information deficit, an increase of local zooplankton abundance in the BIOTRANS area due to lateral advection cannot be totally ruled out.

(3) It is uncertain why no seasonal increase in zooplankton could be detected in the lower bathypelagic zone. Changes could have appeared later in the year due to a longer development time of deep-living bathy- 
pelagic zooplankton, and/or could not be observed with the method used (e.g. the mesh was too coarse to catch naupliar and early copepodid stages). Another explanation may be that the lower bathypelagic zone differs ecologically from the upper bathypelagic zone, which is probably reflected by the reduced decrease in zooplankton abundance at depths below $2500 \mathrm{~m}$ at the studied site (Koppelmann \& Weikert 1992, Weikert \& Koppelmann 1996). This can be due to large-scale resuspension of particles from the sea floor due to abyssal storms, faunistic changes and/or less predation pressure (Weikert \& Koppelmann 1996). Assuming relatively high background values of suspended matter, increased detrital input events may be not sufficient to elicit a seasonal pulse in the mesozooplankton of the deep bathypelagic zone of the BIOTRANS area, or the native fauna is not able to use fast-sinking large material because of its feeding behavior. Due to extensive alterations of organic matter in the water column (Wakeham \& Lee 1993), a further reason may be a decrease in the nutritional quality of particles with increasing depth. At the bathyal deep-sea floor, where detrital particles accumulate episodically, the resulting organic concentrations caused by a large single bloom event might be high enough to trigger a seasonal reaction of the benthic and benthopelagic faunas (Thiel et al. 1988/1989).

\section{Temporal changes in carbon requirements of deep- living zooplankton: the influence on the carbon budget of the deep sea}

Respiration measurements of mixed zooplankton from the bathypelagic zone of the NE Atlantic are lack- ing. Some in situ measurements of deep-living benthic boundary layer zooplankton from the Pacific Ocean exist (Smith 1982, 1985, Smith et al. 1986) and there is some data on potential respiration based on ETS (electron transport system) measurements (Table 7). The ETS data derived from bathypelagic $212 \mu \mathrm{m}$-mesh zooplankton from the Pacific Ocean (King et al. 1978) have been supplemented by ETS measurements using $333 \mu \mathrm{m}$-mesh zooplankton from the Arabian Sea (Koppelmann \& Weikert unpubl. results). The latter data were obtained from horizontal tows at 1000, 2500 and $4000 \mathrm{~m}$ depth centring at $14^{\circ} \mathrm{N}, 64^{\circ} \mathrm{E}$. The ETS analysis was done following the method of Packard (1971), modified by Kenner \& Ahmed (1975). The enzymatic activity was recalculated for in situ temperature using the Arrhenius equation assuming an activation energy of $13.2 \mathrm{kcal} \mathrm{mol} \mathrm{m}^{-1}$ for bathypelagic zooplankton (Packard et al. 1975) to determine the oxygen consumption in $\mu \mathrm{O}_{2} \mathrm{~d}^{-1} \mathrm{~g} \mathrm{wwt}^{-1}$. A respiration/ETS ratio of 0.5 was used to adjust the potential oxygen consumption measured by the ETS method to respiration. This ratio was found by King \& Packard (1975) and was modified by Hernández-León \& Gómez (1996) for the Kenner \& Ahmed (1975) version of the ETS assay.

The ETS activity describes the maximum activity of enzymes associated with the respiratory transport system and has to be converted into in vivo respiration rates. Somero et al. (1983) stated that the enzyme kinetic is affected by high pressure, however, it has little effect on the maximum enzyme activity (Siebenaller \& Somero 1989 and others cited in Childress \& Thuesen 1992), and King \& Packard (1975) found no significant effect on ETS activity between 1 and

Table 7. Respiration rates $\left(\mu \mathrm{l} \mathrm{O}_{2} \mathrm{~d}^{-1} \mathrm{~g} \mathrm{wwt}^{-1}\right)$ of deep-sea mesozooplankton obtained from ETS and in situ measurements

\begin{tabular}{|c|c|c|c|c|c|}
\hline Source & $\begin{array}{l}\text { Depth } \\
\text { (m) }\end{array}$ & $\mathrm{N}$ & $\begin{array}{c}\text { Temperature } \\
\left({ }^{\circ} \mathrm{C}\right)\end{array}$ & $\begin{array}{c}\text { Mean } \\
\left(\mu \mathrm{O}_{2} \mathrm{~d}^{-1} \mathrm{~g}^{-1}\right)\end{array}$ & $\begin{array}{c}\text { Range } \\
\left(\mu \mathrm{l} \mathrm{O}_{2} \mathrm{~d}^{-1} \mathrm{~g}^{-1}\right)\end{array}$ \\
\hline Koppelmann & 1000 & 1 & 8.9 & 980 & - \\
\hline \& Weikert & 2500 & 2 & 2.3 & 580 & $540-620$ \\
\hline (unpubl. results) $^{d}$ & 4000 & 2 & 1.7 & 350 & $320-380$ \\
\hline King et al. & $1000-2000$ & 3 & $4.5-2.1$ & 5830 & $2090-10130$ \\
\hline$(1978)^{\mathrm{b}}$ & $2000-3000$ & 1 & $2.1-1.6$ & 440 & - \\
\hline Smith $(1982)^{\mathrm{c}}$ & 1300 & 8 & 3 & 330 & $240-490$ \\
\hline Smith $(1985)^{d}$ & 2615 & 5 & $1.7-1.8$ & 560 & $400-680$ \\
\hline Smith et al. $(1986)^{\mathrm{e}}$ & 3850 & 10 & 1.8 & 340 & $240-480$ \\
\hline Koppelmann & 1000 & 1 & 6.8 & 820 & - \\
\hline \& Weikert & 2500 & 2 & 3.3 & 630 & $590-680$ \\
\hline (unpubl. results) $^{g}$ & 4000 & 2 & 2.6 & 380 & $350-410$ \\
\hline \multicolumn{6}{|c|}{$\begin{array}{l}{ }^{a} \text { Arabian Sea, ETS data multiplied by } 0.5 \text { for estimated respiration after Hernández-Leon \& Gómez (1996) } \\
\text { "ETS data based on } 21.2 \mu \text { met-zooplankton from the North Pacific } \\
{ }^{c} \text { In situ measurements, Santa Catalina Basin, } 1300 \mathrm{~m} \\
{ }^{d} \text { In situ measurements, East Pacific Rise (Clam field and nonvent area), } 2615 \mathrm{~m} \\
{ }^{\mathrm{e}} \text { In situ measurements, Panama Basin, } 3850 \mathrm{~m}\end{array}$} \\
\hline
\end{tabular}


$100 \mathrm{~atm}$ and at $265 \mathrm{~atm}$. As a drawback, the ETS method is seasonally influenced and responds more slowly than the respiratory rate to environmental changes (Båmstedt 1979, 1980).

The respiration values of the quoted assays (Table 7) obtained from depths between 2000 and $3000 \mathrm{~m}$ and at around $4000 \mathrm{~m}$ are in good agreement despite the different methods applied. Differences exist for shallower bathypelagic depths. The respiration values at $1300 \mathrm{~m}$ measured in situ by Smith (1982) are lower than the ETS-based Arabian Sea data from October 1995, even if the different water temperatures are taken into consideration. Also, the source of the extremely high values of potential respiration between 1000 and $2000 \mathrm{~m}$ published by King et al. (1978) is beyond our knowledge. Considering our own ETS data sets from the upper bathypelagic zone in the Arabian Sea, differences in the physical condition of zooplankton may be a key source of variability, aside from the yet unknown effect of the oxygen minimum layer which extends as deep as $1200 \mathrm{~m}$. In contrast to the ETS data from October 1995, an assay from April 1997 yielded lower values which were in the same order of magnitude as the in situ respiration rates reported by Smith (1982). The zooplankton collected in April 1997 after the NE monsoon contained a higher amount of carcasses, exoskeletons and senescent organisms, in contrast to the well-conditioned assemblage which was studied in October 1995, i.e. after the end of the productive SW monsoon period (Haake et al. 1993). These organisms showed no subjective differences in their condition as compared to the zooplankton collected in the $\mathrm{NE}$ Atlantic in spring and summer. We, therefore, use the October 1995 data from the Arabian Sea, corrected for the in situ temperature of the NE Atlantic by using the Arrhenius equation (Table 7 ), to calculate the oxygen consumption of the NE Atlantic bathypelagic zooplankton. Use of the lower ETS data from April 1997 and the in situ measurements of Smith (1982) for the upper bathypelagic zone will lower the estimated rates by 30 to $40 \%$. These results are shown in parentheses; they do not affect the general conclusions stated in this paper.

There is a dearth of information on the influence of metazoan plankton on the transfer of carbon in the deep sea. We make an attempt to propose (1) a carbon balance for the bathypelagic zooplankton in the temperate NE Atlantic and (2) a carbon budget for the deep-sea community as a whole. We converted the estimated oxygen consumption rates into carbon requirements assuming a respiration factor of 0.85 (King et al. 1978). The resulting values were fitted into a exponential regression to estimate carbon demands of mesozooplankton throughout the water column:

$$
\begin{gathered}
\log \mu \mathrm{gC \textrm {d } ^ { - 1 } \mathrm { g } w \mathrm { wt } ^ { - 1 }}=2.723+\text { Depth } \times-1.19 \times 10^{-4} \\
\mathrm{n}=5 ; \mathrm{r}^{2}=0.917
\end{gathered}
$$

This regression was applied to the midpoints of the NE Atlantic bathypelagic sample intervals, and the results were multiplied by the respective biomass values. According to the integrals over the 1000 to 2250 and 2250 to $4250 \mathrm{~m}$ depth ranges, the upper bathypelagic mesozooplankton potentially required ca 1.26 (0.76) $\mathrm{mg} \mathrm{C} \mathrm{m} \mathrm{m}^{-2} \mathrm{~d}^{-1}$ during spring and 3.80 (2.24) $\mathrm{mg} \mathrm{C}$ $\mathrm{m}^{-2} \mathrm{~d}^{-1}$ in summer. In the lower bathypelagic zone, the demands were $0.35 \mathrm{mg} \mathrm{C} \mathrm{m}^{-2} \mathrm{~d}^{-1}$ in spring and $0.32 \mathrm{mg}$ $\mathrm{C} \mathrm{m}^{-2} \mathrm{~d}^{-1}$ in summer. Using literature sources, Childress \& Thuesen (1992) calculated the biomass crop (1030 $\mathrm{mg}$ wwt $\mathrm{m}^{-2}$ ) and the metabolic carbon flux (0.13 $\left.\mathrm{mg} \mathrm{C}^{-2} \mathrm{~d}^{-1}\right)$ of zooplankton and micronekton in a hypothetical central oceanic region in the depth range from 1000 to $4000 \mathrm{~m}$. Standardised to $1 \mathrm{~g}$ biomass the authors' figure yields a metabolic carbon flux of $0.126 \mathrm{mg} \mathrm{C} \mathrm{g}^{-1} \mathrm{~d}^{-1}$. This value is in the same order of magnitude, though lower by a factor of 2.5 (1.8) and 2.8 (1.7), as our measurements from spring (0.320 [0.221] $\left.\mathrm{mg} \mathrm{C} \mathrm{g}{ }^{-1} \mathrm{~d}^{-1}\right)$ and summer (0.347 [0.216] $\left.\mathrm{mg} \mathrm{C} \mathrm{g}^{-1} \mathrm{~d}^{-1}\right)$, respectively.

We cannot delineate the growth of the zooplankton assemblage at the BIOTRANS site encompassing the time between March to August 1992; however, assuming that the biomass increase between the sampling events was linear, the mesozooplankton required 356 (212) $\mathrm{mg} \mathrm{C} \mathrm{m}^{-2}$ in the upper bathypelagic zone (1050 to $2250 \mathrm{~m}$ ) and $47 \mathrm{mg} \mathrm{C} \mathrm{m} \mathrm{m}^{-2}$ in the lower bathypelagic zone $(2250$ to $4250 \mathrm{~m})$. An additional minimum amount of $392 \mathrm{mg} \mathrm{C} \mathrm{m} \mathrm{m}^{-2}$ was channelled into new body substance, which is reflected by the surplus of biomass in summer as compared to spring. This value was obtained by converting the wet weight biomass via dry weight into carbon. Since the determination of wet weight is highly influenced by the technique used (Wiebe et al. 1975), we applied our own factor of 0.093 $(\mathrm{N}=37, \mathrm{SD}=0.016)$ to calculate the dry weight. This factor was obtained from deep-frozen material taken from integrated MOCNESS samples which had been collected by lowering the device through the water column with the first net open. The carbon content was calculated by multiplying the dry weight by a factor of 0.6 according to Cushing et al. (1958). Overall, as a conservative estimate, 795 (651) $\mathrm{mg} \mathrm{C} \mathrm{m}^{-2}$ was required by the bathypelagic mesozooplankton in the period from spring to summer 1992 (Fig. 4), disregarding losses due to excretion, dissolution and use by higher trophic levels

Concomitant sediment trap deployments at the BIOTRANS station yielded POC (particulate organic carbon) fluxes of 3 to $4 \mathrm{mg} \mathrm{C} \mathrm{m}^{-2} \mathrm{~d}^{-1}$ in March 1992, a minimum in May, and again higher fluxes between 3 to 
$5 \mathrm{mg} \mathrm{C} \mathrm{m} \mathrm{Cl}^{-2} \mathrm{~d}^{-1}$ from June to August at $3500 \mathrm{~m}$ depth (Pfannkuche et al. 1999). The fluxes from $3500 \mathrm{~m}$ were extrapolated to 1000 and $4500 \mathrm{~m}$ using the formula of Martin et al. (1987), which best fits the empirical relationship between the decrease of flux and the increase in depth (Bishop 1989, Jickells et al. 1996). The respective values for spring and summer are 8.8 to 11.7 and 8.8 to $14.6 \mathrm{mg} \mathrm{C} \mathrm{m}^{-2} \mathrm{~d}^{-1}$ at $1000 \mathrm{~m}$ and 2.4 to 3.2 and 2.4 to $4.0 \mathrm{mg} \mathrm{C} \mathrm{m}^{-2} \mathrm{~d}^{-1}$ at $4500 \mathrm{~m}$ depth. Subtracting the carbon flux at $4500 \mathrm{~m}$ from the flux rates at $1000 \mathrm{~m}$ results in an estimated loss of 6.4 to $8.5 \mathrm{mg} \mathrm{C} \mathrm{m}^{-2} \mathrm{~d}^{-1}$ in spring (March) and 6.4 to $10.6 \mathrm{mg} \mathrm{C} \mathrm{m}^{-2} \mathrm{~d}^{-1}$ in summer (June to August) in the bathypelagic zone. These values would fit the carbon requirements of the mesozooplankton in spring (1.61 [1.11] $\left.\mathrm{mg} \mathrm{C} \mathrm{m}^{-2} \mathrm{~d}^{-1}\right)$ and summer (4.12 [2.56] $\mathrm{mg} \mathrm{C} \mathrm{m}^{-2} \mathrm{~d}^{-1}$ ). The mesozooplankton respiration is responsible for 18.9 to $25.1 \%$ of the bathypelagic carbon losses in spring and for 38.9 to $64.4 \%$ in summer. Lampitt (1992) calculated that zooplankton is responsible for $9 \%$ of the remineralisation in a $900 \mathrm{~m}$ thick stratum $100 \mathrm{~m}$ above the sea bed at the less productive $5440 \mathrm{~m}$ deep Madeira Abyssal Plain and stated that higher remineralisation rates possibly occur further up in the water column.

By assuming that mesozooplankton consumes ca $30 \%$ of the carbon used by the microplankton (King et al. 1978, Packard et al. 1988), the combined daily carbon requirements of microplankton and mesozooplankton in the bathypelagic zone are $7.0(4.8) \mathrm{mg} \mathrm{C}$ $\mathrm{m}^{-2} \mathrm{~d}^{-1}$ in spring and $17.9(11.1) \mathrm{mg} \mathrm{C} \mathrm{m}^{-2} \mathrm{~d}^{-1}$ in summer 1992, requirements which were only satisfied in spring, according to the above calculation.

The carbon demands of the benthic community were not assessed in 1992. In situ measurements from previous years showed a similar rate of increase, from $4.4 \mathrm{mg} \mathrm{C} \mathrm{m}^{-2} \mathrm{~d}^{-1}$ in April to $9.3 \mathrm{mg} \mathrm{C} \mathrm{m}^{-2} \mathrm{~d}^{-1}$ in July/ August (Pfannkuche 1992). Weighting the sum of seasonal carbon demands by the pelagic metazoan and benthic faunas gives a share of $61 \%(52 \%)$ for the bathypelagic community in spring and $66 \%(54 \%)$ in summer. The proportions are in accord with theoretical estimates of Jahnke (1996), which yielded a ratio of $55 \%$ for the bathypelagic community and $45 \%$ for the benthic community.

\section{CONCLUSIONS}

Assuming a minimum spring bloom area of 50000 $\mathrm{km}^{2}$ (Newton et al. 1994) in the vicinity of the BIOTRANS site, we estimate that during spring and summer 80.5 (55.5) and $206.0(128.0) \mathrm{t} \mathrm{C} \mathrm{d}^{-1}$, respectively, is released as a minimum amount into the deep water of this area by bathypelagic mesozooplankton respiration. Including the microplankton, the respective

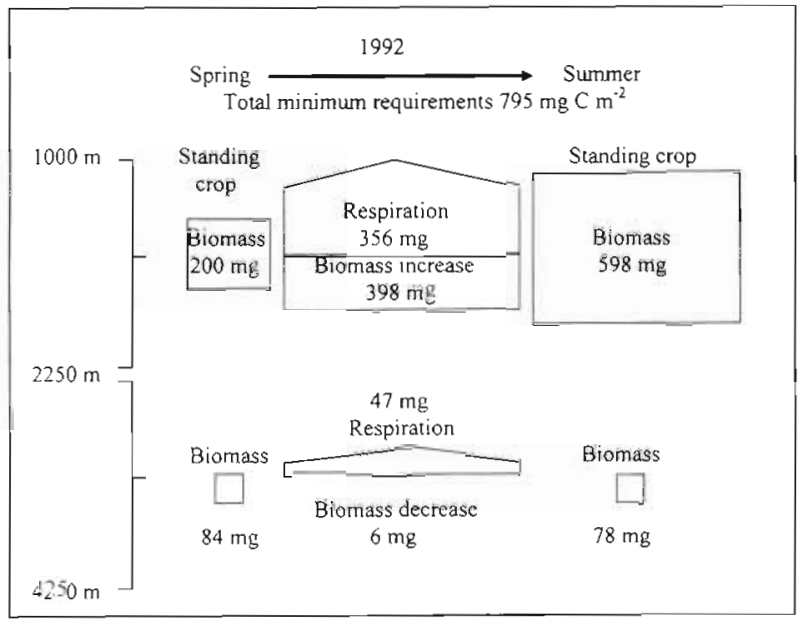

Fig. 4. Carbon requirements of mesozooplankton in the upper and lower bathypelagic zone in the NE Atlantic calculated from ETS data

rough figures would amount to 349 (241) and 893 (555) $\mathrm{t} \mathrm{C} \mathrm{d} \mathrm{d}^{-1}$. This results in mesozooplankton and total zooplankton requirements of $20.2(13.0)$ and $87.4(56.1) \mathrm{kt}$ $C_{1}$ respectively, for the 5 mo period from April to August 1992. The last figure compares to a respiration of $402 \mathrm{kt} \mathrm{C} \mathrm{yr}^{-1}$ per $50000 \mathrm{~km}^{2}$, which is derived from Packard et al.'s (1988) estimate for the bathypelagic zone of the entire Atlantic Ocean. Based on an average primary production (Sathyendrath et al. 1995) of around $9000 \mathrm{kt} \mathrm{C} \mathrm{yr}^{-1}$ ( $\mathrm{ca} 180 \mathrm{~g} \mathrm{C} \mathrm{m}^{-2} \mathrm{yr}^{-1}$ ) in an area equivalent in size as above around the BIOTRANS site, approximately $2 \%$ of the carbon production is respired by the bathypelagic zooplankton on the scale of a year. This value is at the upper end of the range of surface primary production which reaches the benthos community at the bathyal sea floor.

The respired carbon can be stored for periods in the order of several 100 years, which is the estimated time scale of mixing for the ocean (Broecker \& Peng 1982, Southam \& Peterson 1985, Lampitt \& Antia 1997). Thus, bathypelagic zooplankton is expected to be an important element of a mechanism acting on a large scale by means of which carbon can be redistributed to the sea surface and atmosphere. Even that part of the settling carbon which is not respired, but formed into new dissolved and particulate organic substances by the deep-living fauna, will not necessarily be removed from the ocean-atmosphere system by export to the sea floor and subsequent incorporation into the sediment (Bender \& Heggie 1984). Implicitly, losses by metabolism (respiration and excretion) would counteract the rapid transfer of particulate organic material to depth by the 'ladder of migration' (Vinogradov 1962). The ecological relevance of this 
migration in bathyal and abyssal depths is disputed (Wakefield \& Smith 1990) and has to be substantiated by detailed data sets.

Our estimate of the carbon requirement of NE Atlantic bathypelagic zooplankton is primarily challenged by the underlying data on respiration which were obtained from a different assay and, therefore, could have been influenced by differences in the metabolic activity of zooplankton. Notwithstanding, even including theoretical considerations (Jahnke 1996), there is reason to assume that the measured carbon flux into the bathyal deep sea seems to barely fulfil the demands of the native biota, even if zooplankton is considered alone. This result may also underline the acknowledged problem of significant errors in flux estimates derived from sediment traps (e.g. Gust et al. 1992, Beaulieu \& Smith 1998), which may be between 15 and $30 \%$ in the deep North Atlantic (Scholten et al. 1998).

The assessed contrast in the abundance of bathypelagic zooplankton between spring and summer draws attention to the existence of temporal variability in the bathypelagic zone at a midlatitude oceanic site, and it gives a first hint of the magnitude of variability that can operate. One should also take into account that the bathypelagic fauna may exert control on the magnitude and timing of sediment community activity. These aspects taken together are not trivial and would be important for an improved understanding of the modes of transfer and cycling of carbon in the interior of the ocean.

Forthcoming investigations on the flux of particles in the deep ocean must be well coordinated in space and time with fine-stratified zooplankton sampling during different seasons and in different regions in order to elucidate (1) the suggested linkage of episodes of increased particle flux with the increment of bathypelagic organisms and (2) the mediatory role of deepliving zooplankton with a view to benthopelagic coupling. An improved faunal assessment of deepliving zooplankton and its structures together with measurements of reproduction and physiological activities (respiration, excretion) are of principal relevance for a better understanding of the function of the deepsea ecosystem.

Acknowledgements. We thank W. Beckmann, B. Christiansen, B. Drüke, J. Dutz, H. Fabian, A. Kähler, K. Lampe, B. Martin, L. Neugebohrn, and S. Uthicke for supporting the field sampling and individual counting. $H$. Thiel and $S$. Scheibe read an earlier version of the manuscript. U. Witte and 2 anonymous reviewers made useful comments on the manuscript. We also thank the crew of the RV 'Meteor' for skilful assistance. The investigations were supported by funds to $\mathrm{H}$. Thiel (BMBF 03F0565A) and H.W. (DFG We $695 / 15$ and BMBF 03F0137A, TP 14).

\section{LITERATURE CITED}

Alldredge AL, Silver MW (1988) Characteristics, dynamics and significance of marine snow. Prog Oceanogr 20:41-82

Angel MV, Baker AdeC (1982) Vertical distribution of the standing crop of plankton and micronekton at three stations in the Northeast Atlantic. Biol Oceanogr 2:1-30

Angel MV, Hargreaves P, Kirkpatrick P, Domanski P (1982) Low variability in planktonic and micronektonic populations at $1000 \mathrm{~m}$ depth in the vicinity of $42^{\circ} \mathrm{N} 17^{\circ} \mathrm{W}$; evidence against diel migratory behavior in the majority of species. Biol Oceanogr 1:287-319

Båmstedt U (1979) Seasonal variation in the respiratory rate and ETS activity of deep-water zooplankton from the Swedish West Coast. In: Naylor ED. Harnoll RG (eds) Cyclic phenomena in marine plants and animals. Pergamon Press, Oxford, p 267-274

Båmstedt U (1980) ETS activity as an estimator of respiratory rate of zooplankton populations, the significance of variations in environmental factors. J Exp Mar Biol Ecol 42: $267-283$

Beaulieu SE, Smith KL Jr (1998) Phytodetritus entering the benthic boundary layer and aggregated on the sea floor in the abyssal NE Pacific: macro- and microscopic composition. Deep-Sea Res II 45:781-815

Bender ML, Heggie DT (1984) Fate of organic carbon reaching the deep-sea floor: a status report. Geochim Cosmochim Acta 48:977-986

Billett DSM, Lampitt RS, Rice AL, Mantoura RFC (1983) Seasonal sedimentation of phytoplankton to the deep sea benthos. Nature 302:520-522

Bishop JDD, Shalla SH (1994) Discrete seasonal reproduction in an abyssal peracarid crustacean. Deep-Sea Res 41: $1789-1800$

Bishop JKB (1989) Regional extremes in particulate matter composition and flux: effects on the chemistry of the ocean interior. In: Berger WH, Smetacek VS, Wefer G (eds) Productivity of the ocean: present and past. John Wiley \& Sons, Chichester, p 117-137

Broecker WS, Peng TH (1982) Tracers in the sea. LamontDoherty Geological Observatory, Palisades, NY

Childress JJ, Thuesen EV (1992) Metabolic potential of deepsea animals: regional and global scales. In: Rowe GT, Pariente $V$ (eds) Deep-sea food chains and the global carbon cycle. Kluwer Academic Publishers, Dordrecht, p 217-236

Cushing DH, Humphrey GF, Banse K, Laevastu T (1958) Report of the committee on terms and equivalents. Rapp P-V Reun Cons Int Explor Mer 144:15-16

Deuser WG, Muller-Karger FE, Evans RH, Brown OB, Esaias WE, Feldmann GC (1990) Surface-ocean color and deepocean carbon flux: how close a connection? Deep-Sea Res $37: 1331-1343$

Diel S (1988) Zur Lebensgeschichte dominanter Copepodenarten (Calanus finmarchicus, C. glacialis, C. hyperboreus, Metridia longa) in der Framstraße. Ber Polarforsch 88: $1-113$

Gapishko AI (1980) Relationships between trophic groups in the zooplankton of the Gulf of Aden. Hydrobiol J 16 : $36-41$

Gardener WD, Sullivan LG, Thorndike EM (1984) Long-term photographic, current, and nephelometer observations of manganese nodule environments in the Pacific. Earth Planet Sci Lett 70:95-109

Gooday A.J (1996) Epifaunal and shallow infaunal foraminiferal communities at three abyssal NE Atlantic sites subject to differing phytodetritus input regimes. Deep-Sea Res 43:1395-1421 
Gowing MM. Wishner KF (1992) Feeding ecology of benthopelagic zooplankton on an eastern tropical Pacific seamount. Mar Biol 112:451-467

Gust G, Byrne RH, Bernstein RE, Betzer PR, Bowles W (1992) Particle fluxes and moving fluids: experiences from synchronous trap collections in the Sargasso Sea. Deep-Sea Res 39:1071-1083

Haake B, Ittekkot V, Nair RR, Curry WB (1993) Seasonality and interannual variability of particle fluxes to the deep Arabian Sea. Deep-Sea Res 40:1323-1344

Hecker B (1990) Photographic evidence for rapid flux of particles to the seafloor and their transport down the continental slope. Deep-Sea Res 37:1773-1782

Hernández-León S, Gómez M (1996) Factors affecting the respiration/ETS ratio in marine zooplankton. J Plankton Res 18:239-255

Hirche HJ (1983) Overwintering of Calanus finmarchicus and Calanus helgolandicus. Mar Ecol Prog Ser 11:281-290

Hoge FE, Swift RN (1993) The influence of chlorophyll pigment upon upwelling spectral radiances from the North Atlantic Ocean: an active-passive correlation spectroscopy study. Deep-Sea Res II 40:265-278

Honjo S, Manganini SJ (1993) Annual biogenic particle fluxes to the interior of the North Atlantic Ocean; studied at $34^{\circ} \mathrm{N}-21^{\circ} \mathrm{W}$ and $48^{\circ} \mathrm{N}-21^{\circ} \mathrm{W}$. Deep-Sea Res II 40:587-607

Jahnke RA (1996) The global ocean flux of particulate organic carbon: areal distribution and magnitude. Global Biogeochem Cycles 10:71-88

Jickells TD, Newton PP, King P, Lampitt RS, Boutle C (1996) A comparison of sediment trap records of particulate fluxes from 19 to $48^{\circ} \mathrm{N}$ in the northeast Atlantic and their relation to surface water productivity. Deep-Sea Res 43:971-986

Kaartvedt S (1996) Habitat preference during overwintering and timing of seasonal vertical migration of Calanus finmarchicus. Ophelia 44:145-156

Kenner RA, Ahmed SI (1975) Measurement of electron transport activities in marine phytoplankton. Mar Biol 33: $119-128$

King FD, Packard TT (1975) Respiration and the activity of the respiratory electron transport system in marine zooplankton. Limnol Oceanogr 20:849-854

King FD, Devol AH, Packard TT (1978) On plankton biomass and metabolic activity from the eastern tropical North Pacific. Deep-Sea Res 25:689-704

Koeve $W$, Podewski S, Pollehne $F$, Zeitzschel B, Jochem $F$, Kähler $P$, Dettmer A, Deckers M, Haupt O, Reitmeier $S$, Bohm S, Fritsche P, Werner R, Sellmer C (1993) Planktological investigations during the winter-spring-summer transition at $47^{\circ} \mathrm{N} 20^{\circ} \mathrm{W}$ (JGOFS). In: Pfannkuche $\mathrm{O}$ Duinker JC, Graf G, Henrich R, Thiel H, Zeitzschel B (eds) Nordatlantik 92 Reise Nr. 21 vom 16 März-31 August 1992. Meteor Berichte 93-4, Hamburg, p 100-115

Koppelmann R (1994) Distribution and composition of gelatinous detrital material from closing net hauls in the NE Atlantic. Mar Biol 118:755-759

Koppelmann R (1995) Saisonale Veränderungen in bathypelagischen Zooplanktonbeständen des Nordostatlantiks. PhD thesis, University of Hamburg

Koppelmann R, Weikert H (1992) Full-depth zooplankton profiles over the deep bathyal of the NE Atlantic. Mar Ecol Prog Ser 86:263-272

Kouwenberg J (1993) Sex ratio of calanoid copepods in relation to population composition in the northwestern Mediterranean. Crustaceana 64:281-299

Lampitt RS (1985) Evidence for the seasonal deposition of detritus to the deep-sea floor and its subsequent resuspension. Deep-Sea Res 32:885-897
Lampitt RS (1992) The contribution of deep-sea macroplankton to organic remineralisation: results from sediment trap and zooplankton studies over the Madeira Abyssal Plain. Deep-Sea Res 39:221-233

Lampitt RS, Antia AN (1997) Particle flux in deep seas: regional characteristics and temporal variability. DeepSea Res 44:1377-1403

Lochte K (1992) Bacterial standing stock and consumption of organic carbon in the benthic boundary layer of the abyssal North Atlantic. In: Rowe GT, Pariente V (eds) Deep-sea food chains and the global carbon cycle. NATO ASI Series Vol C360, Kluwer Academic Publishers, Dordrecht, $p$ 1-10

Loubere P (1998) The impact of seasonality on the benthos as reflected in the assemblages of deep-sea foraminifera. Deep-Sea Res 45:409-432

Mantyla AW, Reid JL (1983) Abyssal characteristics of the World Ocean waters. Deep-Sea Res 30:805-833

Martin JH, Knauer GA, Karl DM, Broenkow WW (1987) VERTEX: carbon cycling in the northeast Pacific. Deep-Sea Res 34:267-286

Menzies RJ (1965) Conditions for the existence of life on the abyssal sea floor. Oceanogr Mar Biol Annu Rev 3:195-210

Mittelstaedt E, Bock M, Bork I, Klein $\mathrm{H}_{1}$ Nies $\mathrm{H}$, Schauer U (1986) Ausbreitungsbedingungen für Stoffe in großen Ozeantiefen. Nordostatlantisches Monitoring Programm. Deutsches Hydrographisches Institut, Hamburg

Mosely HN (1880) Deep-sea dredging and life in the deep-sea III. Nature 21:591-593

Newton PP, Lampitt RS, Jickells TD, King P, Boutle C (1994) Temporal and spatial variability of biogenic particle fluxes during JGOFS northeast Atlantic process studies at $47^{\circ} \mathrm{N}$ $20^{\circ}$ W. Deep-Sea Res 41:1617-1642

Packard TT (1971) The measurement of respiratory electron transport activity in marine phytoplankton. J Mar Res 29: 235-244

Packard TT, Devol AH, King FD (1975) The effect of temperature on the respiratory electron transport system in marine plankton. Deep-Sea Res 22:237-249

Packard TT, Denis M, Rodier M, Garfield P (1988) Deepocean metabolic $\mathrm{CO}_{2}$ production: calculations from ETS activity. Deep-Sea Res 35:371-382

Parsons TR, Lalli CM (1988) Comparative oceanic ecology of the planktonic communities of the subartic Atlantic and Pacific Oceans. Oceanogr Mar Biol Annu Rev 26:317-359

Pfannkuche O (1992) Organic carbon flux through the benthic community in the temperate abyssal Northeast Atlantic. In: Rowe GT, Pariente V (eds) Deep-sea food chains and the global carbon cycle. NATO ASI Series Vol C360, Kluwer Academic Publishers, Dordrecht, p 183-198

Pfannkuche $O$ (1993) Benthic response to the sedimentation of particulate organic matter at the BIOTRANS station, $47^{\circ} \mathrm{N}, 20^{\circ} \mathrm{W}$. Deep-Sea Res II 40:135-150

Pfannkuche O, Lochte K (1993) Open ocean pelago-benthic coupling: Cyanobacteria as tracers of sedimenting salp faeces. Deep-Sea Res 40:727-737

Pfannkuche $O$, Duinker JC, Graf $G$, Henrich $R_{1}$ Thiel $H_{1}$ Zeitzschel B (1993) Nordatlantik 92, Reise Nr. 21 vom 16. März - 31. August 1992. Meteor Berichte, Hamburg 93-4

Pfannkuche $O$, Boetius $A$, Lochte $K$, Lundgreen $U$, Thiel $H$ (1999) Responses of deep-sea benthos to sedimentation pattern in the North-East Atlantic in 1992. Deep-Sea Res 46:573-596

Rice AL, Billett DSM, Fry J, John AWG, Lampitt RS, Mantoura RFC, Morris RJ (1986) Seasonal deposition of phytodetritus to the deep-sea floor. Proc R Soc Edinburgh Sect B 88: $265-279$ 
Rice AL, Thurston MH, Bett BJ (1994) The IOSDL DEEPSEAS programme: introduction and photographic evidence for the presence and absence of a seasonal input of phytode. tritus at contrasting abyssal sites in the northeastern Atlantic. Deep-Sea Res 41:1305-1320

Riemann F (1989) Gelatinous phytoplankton detritus aggregates on the Atlantic deep-sea bed. Structure and mode of formation. Mar Biol 100:533-539

Robinson AR, McGillicuddy DJ, Calman J, Ducklow HW, Fasham MJR, Hoge FE, Leslie WG, McCarthy JJ, Podewski S, Porter DL, Saure G, Yoder JA (1993) Mesoscale and upper ocean variabilities during the 1989 JGOFS bloom study. Deep-Sea Res II 40:9-36

Roe HSJ (1988) Midwater biomass profiles over the Madeira Abyssal Plain and the contribution of copepods. Hydrobiologia 167/168:169-181

Sathyendrath S, Longhurst A, Caverhill CM, Platt T (1995) Regionally and seasonally differentiated primary production in the North Atlantic. Deep-Sea Res 42:1773-1802

Savidge G, Turner DR, Burkhill PH, Watson AJ, Angel MV, Pingree RD, Leach H, Richards KJ (1992) The BOFS 1990 Spring Bloom Experiment: temporal evolution and spatial variability of the hydrographic field. Prog Oceanogr 29: $235-281$

Scholten J, Vogler S, Mangini A, Rutgers van der Loeff $M$, Wanieck J, Koeve W Stoffers P (1998) Trapping effiencies of sediment traps from the deep North Atlantic: the ${ }^{230} \mathrm{Th}$ calibration. In: Pätzold M, Wefer G (eds) Bericht über den 6. JGOFS-Workshop am 4./5. 12.1997 in Bremen. Ber Fachbereich Geowissenschaften Univ Bremen 109:57

Siebenaller JF, Somero GN (1989) Biochemical adaptation to the deep-sea. Crit Rev Aquat Sci 1:1-25

Smith KL Jr (1982) Zooplankton of a bathyal benthic boundary layer: in-situ rates of oxygen consumption and ammonium excretion. Limnol Oceanogr 27:461-471

Smith KL Jr (1985) Macrozooplankton of a deep sea hydrothermal vent: in situ rates of oxygen consumption Limnol Oceanogr 30:102-110

Smith KL Jr, Baldwin RJ (1984) Seasonal fluctuations in deepsea sediment community oxygen consumption: central and eastern North Pacific. Nature 307:624-625

Smith KL Jr, Carlucci AF, Williams PM, Henrichs SM, Balddwin RJ, Graven DB (1986) Zooplankton and bacterioplankton of an abyssal benthic boundary layer: in situ rates of metabolism. Oceanol Acta 9:47-55

Smith KL Jr, Kaufmann RS, Baldwin RJ (1994) Coupling of near-bottom pelagic and benthic processes at abyssal depths in the eastern North Pacific. Limnol Oceanogr 34: $1101-1118$

Sokal RR, Rohlf FJ (1969) Biometry. WH Freeman \& Company, San Francisco

Somero GN, Siebenaller JF, Hochachka PW (1983) Biochemical and phsiological adaptations of deep-sea animals. In: Rowe GT (ed) Deep-sea biology, the sea. Vol 8. Wiley \& Sons, New York, p 261-330

Southam JR, Peterson WH (1985) Transient response of the marine carbon cycle. In: Sundquist ET, Broecker WS (eds) The carbon cycle and atmospheric $\mathrm{CO}_{2}$ : natural variations archean to present. Geophys Monog 32:89-98

Steedman HF (1976) General and applied data on formaldehyde fixation and preservation of marine zooplankton. In: Steedman HF (ed) Zooplankton fixation and preservation. Monographs on oceanographic methodology 4, UNESCO Press, Vendôme, p 103-154

Steinberg DK, Pilskaln CH, Silver MW (1998) Contribution of zooplankton associated with detritus to sediment trap 'swimmer' carbon in Monterey Bay, California, USA. Mar Ecol Prog Ser 164:157-166

Stienen C, Beckmann W, Zeitzschel B (1988) Patterns of a spring mass-sedimentation. EOS Trans 69:1117

Sverdrup HU, Johnson MW, Fleming RH (1949) The oceans, their physics, chemistry, and general biology. PrenticeHall, New York

Thiel H, Pfannkuche O, Schriever G, Lochte K, Gooday AJ, Hemleben C, Mantoura RFG, Turley CM, Patching JW, Riemann F (1988/1989) Phytodetritus on the deep sea floor in a central oceanic region of the northeast Atlantic. Biol Oceanogr 6:203-239

Timonin AG (1971) The structure of plankton communities of the Indian Ocean. Mar Biol 9:281-289

Tranter DJ (1962) Zooplankton abundance in Australasian waters. Aust J Mar Freshwat Res 13:106-142

Turley CM, Lochte K (1990) Microbial response to the input of fresh detritus to the deep-sea bed. Palaeogeogr Palaeoclimatol Palaeoecol (Global Planetary Change Sec) 89:3-23

Tyler PA (1995) Conditions for the existence of life at the deep-sea floor: an update. Oceanogr Mar Biol Annu Rev 33:221-244

Vinogradov ME (1962) Feeding of the deep-sea zooplankton. Rapp P.V Cons Int Explor Mer 153: 114-120

Vinogradov ME (1968) Vertical distribution of the oceanic zooplankton. Academy of Science of the USSR. Institute of Oceanography, translated by Israel Program for Scientific Translation Ltd, Keter Press, Jerusalem (1970) (in Russian)

Wakefield WW, Smith KL Jr (1990) Ontogenetic vertical migration in Seastolobus altivelis as a mechanism for transport of particulate organic matter at continental slope depths. Limnol Oceanogr 35:1314-1328

Wakeham SG, Lee C (1993) Production, transport, and alteration of particulate organic matter in the marine water column. In: Engel MH, Macko SA (eds) Organic geochemistry: principles and applications. Plenum Press, New York p $145-169$

Watson AW, Robinson C, Robertson JE, Williams PJleB, Fasham MJR (1991) Spatial variability in the sink for atmospheric carbon dioxide in the North Atlantic. Nature (Lond) 350:50-53

Weikert H, Koppelmann R (1996) Midwater zooplankton profiles from the temperate ocean and partially landlocked seas. A re-evaluation of interoceanic differences. Oceanol Acta 19:657-664

Weikert H, Trinkaus S (1990) Vertical mesozooplankton abundance and distribution in the deep Eastern Mediterranean Sea SE of Crete. J Plankton Res 12:601-628

Wiebe PH, Boyd SH, Cox JL (1975) Relationships between zooplankton displacement volume, wet weight, dry weight, and carbon. Fish Bull US 73:777-786

Wiebe PH, Morton AW, Bradley AM, Backus RH, Craddock JE, Barber V, Cowles TJ, Flierl GR (1985) New developments in the MOCNESS, an apparatus for sampling zooplankton and micronekton. Mar Biol 87:313-323

Wishner KF (1980) Aspects of the community ecology of deepsea benthopelagic plankton with special attention to gymnopleid copepods. Mar Biol 60:179-187

Yoder JA, Aiken J, Swift RN, Hoge FE, Stegmann PM (1993) Spatial variability in near-surface chlorophyll a fluorescence measured by the Airborne Oceanographic Lidar (AOL). Deep-Sea Res II 40:37-54

Zeitzschel B, Lenz J, Thiel H, Boje R, Passow U, Stuhr A (1990) Expediton Plankton '89 - Benthos '89, Reise Nr. 10 vom 19. März-31 August 1989. Meteor Berichte, Hamburg $90-1$ 